N. $1902=$ In Neumann's Notes sur les Ixodidés I.

N. $1904=1$ Ibid. II.

N. $1906=I b i d$. IV.

Newell Coll. $=$ In the collection of Prof. Wilmon Newell.

Niles $1900=$ Recorded by Dr. E. P. Niles in Bulletin No. 114 of the Va. Agr'l Exp. Station.

N. Y. S. M. Coll.=In the collection of the New York State Museum. Osb. Coll. =In the collection of Prof. Her bert Osborn.

Pack. Amer. Nat. 1868=Recorded in American Naturalist, Vol. II.

Pack. Ann. Rep. 1869=Recorded in First Annual Report of the Pea. body Academy of Science.

Pack. Amer. Nat. $1869=$ Recorded in American Naturalist, Vol. III. Pack. Guide=Recorded in Packard's Guide to the Study of Insects. S. and S. 1901=Recorded in Salmon and Stiles work on Cattle Ticks. Say $1821=$ Recorded by Say in the Journ. Acad. Nat. Sci. of Phila. II. Sim. Aub. and Noc. 1909=Recorded in article by Simond, Aubert and Noc in Comp. Rend. Soc. Biol., Paris, Vol. 66.

Stiles Coll. =In the collection of Dr. C. W. Stiles.

Washb. Coll. =In the collection received from Prof. F. L. Washburn. W. and W. $1909=$ Recorded by Drs. W. B. Wherry and D. C. Wellman in Entomological News, Vol. XX, p. 376 (1909).

\title{
THE IDENTITY AND SYNONYMY OF SOME OF OUR SOFT SCALE-INSECTS
}

By J. G. SANDERs, Bureau of Entomology, Washington, $D . G$.

So much confusion and misapprehension concerning the identity and classification of our soft scales has arisen during the past score of years that the average entomologist has been unable to determine the common species with any degree of certainty. This deplorable condition of our knowledge of this group of scale insects has been to a great extent the result of injudicious and hasty conclusions com. bined with scattered, meagre, unillustrated descriptions.

There has always been a tendency among entomologists, in dealing with insects belonging to the lawer groups of Homoptera-Coccidæ, Aleyrodidæ, Aphididæ- to lay too much stress upon the particular host plant involved. The fact that a certain colony of insects, although apparently quite similar to another colony on its normal food plant, is found on a new food plant has influenced many entomologists to 
describe as a new species the colony on the supposedly abnormal food plant.

Again, variations in size, color and vestiture have misled many to describe a mere variation as a new species or variety. Then, too, it was generally conceded by the early entomologists that the same species of such sedentary insects as coccids could not live on different food plants especially if the hosts belonged to different genera. A sentence in Fitch's original note-book expresses his views on this subject, when he describes the common oyster-shell scale as a new species because he found it on the dogwood (Cormus stolonifera), and adds: "Certainly there is the same ground for deeming the species of this genus, which occur upon plants of different genera, to be distinct species, that there is in the genus Lecanium." As the result of this idea, there are more than forty species and many more varieties of the genus Lecanium described in Fitch's note-book; but fortunately the majority of these descriptions never appeared in print. This idea, prevailing in the time of Linnæus, Geoffroy, Gmelin, Modeer, Fabricius, Burmeister, Schrank, Bouché and Boisduval, has resulted in the publication of a multitude of descriptions of supposedly new species, many of which have been subsequently reduced to synonymy. Unfortunately many of these names still remain as valid species in our catalogues; especially in the non-diaspine groups, and more especially those species of the genus Lecanium. Moreover, within the last decade or two, many species have been deseribed and published here and there, from insufficient material, and without the careful study and comparison with other species which are nearly related, and with but little regard for the individual variations which are bound to appear in insects so absolutely dependent upon the kind and condition of their host plants as are the sedentary scale-insects. It is most unreasonable to expect to find a perfectly formed and fully developed Lecanium or Pulvinaria on a twig or stem of 1-16 inch diameter on a starved plant, when the normal form would appear only on the flat surface of a leaf or a large stem in vigorous growth. Prof. Robert Newstead in his Monograph of the British Coccidæ and more recently Dr. Paul Marchal, of Paris, have done some valuable work in the reduction of the synonyms of the early students of scale insects, and there is still much to be done.

The writer has been especially fortunate during the past five years to have access to the finest collection of Coccida in the world; a collection several times the value of any other in existence on account of the large percentage of type and cotype material; the national collection at Washington at the present time containing upwards of 
850 types and cotypes, material of many other species, and thousands of slide preparations. The loan of the important Coccid collection of the late Wm. Maskell, of New Zealand, and the study of his types, have cleared up several doubtful classifications and confirmed several synonyms.

The following discussion of species and synonyms will necessarily be brief and general and will include only the more common species occurring in this country, with occasional references to their distribution in foreign countries. In a subsequent paper to be published by the U. S. Bureau of Entomology, the writer will review the genus Lecanium and discuss more fully the identity and synonymy of the species.

The writer retains the name Lecanium for some of those species which have been classified under Eulecanium, because it is impossible to eliminate Lecanium from our Coccid nomenclature. At least one species of the several included by Burmeister under bis genus in the original description in Handbuch der Entomologie, II Band, p. 69 (1835), must be retained as the type. All the species which Burmeister really placed under his genus have been removed to other genera except persicce, which should be considered the type. Eulecanium becomes a synonym of Lecanium.

This paper is submitted for publication with the permission of Dr. L. O. Howard, Chief of Bureau.

\section{The Greenhouse Orthezia \\ Orthezia insignis Dougl.}

Plate 19, Fig. 10

Orthezia insignis Dougl., Jn. Quekett Micr. Club, p. 169 (1887).

Orthezia nacrea Buckton, Ind. Mus. Notes, III, 3, p. 103 (1894).

In tropical regions this scale insect is generally known as the Lantana bug, because of its predilection for that plant. It occurs only in greenhouses in temperate regions, where it attacks principally Lantana, Coleus, Citrus spp., Verbena, Chrysanthemum, Ipomoea, Capsicum, etc., and is a difficult pest to eradicate.

The adult female with her fully developed, fluted white ovisac and marginal fringe of white waxy laminæ is a beautiful insect. This species is readily distinguished from all other species of the genus by the large area of the dorsum which is without a waxy covering, revealing the dark green body color.

All the species of this genus bear these white waxy laminæ in characteristic arrangement. 


\section{The Pit-Making Oak Scale}

Asterolecanium variolosum (Ratz.)

Plate 19, Fig. 11

Coccus variolosus Ratz., Tharander Jahrbuch, p. 187 (1870).

Asterolecanium quercicola Sign., An. Soc. Ent. Fr., 4, X, p. 279 (1870).

Lecanium quercicola Altum, Forstzoölogie, III, pt. 2, p. 365 (1882).

Asterodiaspis quercicola Rübs., Berl. Ent. Zeit., XXXIX, p. 200 (1894).

Coccus quercicola Eckst., Forstzoölogie, p. 556 (1897).

Asteŗolecanium variolosum Ckll., Pr. Ac. N. Sci. Ph., p. 269 (1899).

This species is the only one of its genus which is found outside of greenhouses in the northern section of this country. It is a native of the Palearctic region and lives only on various species of oaks.

There have been many references in literature to this scale under the name $A$. quercicola Bouché, but Bouché's original description undoubtedly refers to what is known as Aspidiotus zonatus Frauenf. Ratzeburg's description of variolosum is good and is illustrated by fair figures.

Reports are at hand of its occurrence in Massachusetts, Connecticut, New York, Pennsylvania, Ohio, Michigan, Maryland, New Jersey, Virginia, North Carolina, District of Columbia and Ontario.

This scale is nearly circular in outline and somewhat convex, delicately ridged transversely, and yellowish-green to bronze green in color when alive. After the death of the female the body shrinks, and becomes reddish brown, the color showing through the anterior part of the test. Diameter about $2 \mathrm{~mm}$. The adult female lacks legs and antenne and exhibits few microscopic characters other than the marginal row of figure 8 pores.

\section{The Long-Tailed Mealy Bug \\ Pseudococcus adonidum (Linn.). \\ Plate 19, Fig. 1}

Coccus adonidum Linn., Syst. Nat., Ed. XII, p. 140 (1767).

Pseudococous adonidum Westw., Mod. Class. Ins., I, Synop., p. 118 (1839). Coocus liliacearum Bouche, Stett. Ent. Zeit,, p. 300 (1844).

Coccus tuliparum Bouche, Stett. Ent. Zeit., p. 301 (1844).

Coccus zamice Lucas, Bul. Soc. Ent. Fr., 3, V, p. CVII (1855).

Dactylopius longispinus Targ., Catalogue, p. 32 (1869).

Dactylopius hoye Sign., An. Soc. Ent. Fr., 5, V, p. 317 (1875).

Dactylopius pteridis Sign., An. Soc. Ent. Fr., 5, V, p. 321 (1875).

Dactylopius longifilis Comst., Rep. U. S. Dep. Agr., 1880, p. 344 (1881).

The general appearance of this soft, mealy, segmented scale-insect is well shown in the accompanying plate. There are but few species 
of this genus exhibiting the very long caudal waxy filaments, and one is pretty safe in identifying as this species the common longtailed mealy-bugs of our greenhouses. It occurs on many plants but its. range of hosts is hardly as great as that of the short-tailed species, Pseudococcus citri.

There are seventeen white waxy marginal filaments of various. lengths on each side of the body which is covered lightly with powdery wax. The four posterior filaments are sometimes longer than the body. The segments are quite distinct. On each side of the anal lobes are two microscopic sharp spines surrounded by a circle of closely-grouped pores, easily distinguishable from the scattered arrangement in citri.

There is no reason why Linnæus' name of this insect should be discarded in favor of longispinus Targ., when we have such a good description of the insect in Systema Naturæ, Ed. XII, even though thename had been used previously in Fauna. Suecica and omitted from Ed. $\mathbf{X}$.

Bouché's species liliacearum and tuliparum are undoubtedly synonyms differing according to description only in size, and both occur on plants of the same group and under similar conditions. Bouché says they are near adonidum. Coccus zamia Lucas was described from Zamia australis and $Z$. spiralis, plants originally from Australia, but growing for some time in the Paris Botanic Gardens where adonidum was abundant. The writer has seen Zamia sp. literally covered beneath with Pseud. adonidum and Saissetia hemisphcerica (Targ.).

Maskell in 1895 [Ann. Mag. N. H., 6, XVI, p. 133 (1895)] considered Dact. liliacearum, $D$. tuliparum and $D$. hoyce to be synonyms of $D$, adonidum (Linn.).

\section{The Short-Tailed Mealy Bug \\ Pseudococcus citri (Risso)}

Plate 19, Fig. 2

Dorthesia citri Risso, Essai, Hist. Nat. des Oranges (1813).

Coccus citri Bdv,, Ent. Hort., p. 348 (1867).

Dactylopinls citri Sign., An. Soc. Ent. Fr. (5), v. p. 312 (1875).

Lecanium phyllococcus Ashm., Can. Ent., XI, p. 160 (1879).

Dactylopius brevispinus Targ., Annali di Agr., p. 137 (1881).

Dactylopius destructor Comst., Rep. U. S. Dep. Agr., 1880, p. 342 (1881).

Pseudococcus citri Fernald, Cat. of Coccidæ, p. 99 (1903).

This very common mealy-bug infests so many species of plants that it would be much easier to list those not affected, so omnivorous is it- 
in habit. The accempanying photograph will convey an idea of its superficial appearance more accurately than description. When many specimens are massed on a plant the filaments are disarranged and intermingled so that the characteristic appearance is somewhat lacking. The mid-dorsal longitudinal brownish band is quite characteristic of this species. The microscopical characters of the anal lobes readily distinguish it from adonidum, by the two spines and scattered pores as contrasted with the closely grouped pores in the latter species.

The ovisacs of citri as well as adonidum are normally of a flattened cylindrical form constructed of loose waxy threads, but when the insects are crowded the ovisacs are irregularly massed.

This scale has been a pest in citrus groves in southern Europe for many years, and now its damage is assuming alarming proportions in the lemon groves of southern California. Every greenhouse propagator knows this insect as a pernicious and aggravating pest.

\section{The Cottony Maple-Scale \\ Pulvinaria vitis (Linn.)}

Coccus vitis Linn., Syst. Nat., Ed. X, 1, p. 456 (1758).

Coccus innumerabilis Rathv., Penn. Farm Journ., p. 256 (1854).

Lecanium pyri Fitch (in part), Tr. N. Y. Agr. Soc., p. 809 (1854).

Lecanium maclurce Fitch, Country Gentleman, V, p. 38 (1855).

Lecanium acericorticis Fitch, 6th Rep. Ins. N. Y., p. 775 (1859).

Lecanium acerella Rathv., Lancaster Farmer, p. 101 (1876).

Pulvinaria innumerabilis var. occidentalis Ckll., The Entom., XXX, p. 13 (1897).

Pulvinaria inmumerabilis var. tiliae King \& Ckll., Psyche, VIII, p. 286 (1898).

Pulvinaria hunteri King, Can. Ent., XXXIII, p. 144 (1901).

Pulvinaria simplex King, Mitth. Schw. Ent. Ges. (10), X, p. 475 (1903).

This is a well known scale in the United States, which in Europe is popularly known as the vine cottony scale. It is one of the most conspicuous scales of this country when the ovisac of the female is fully developed, and is considered a variable pest from year to year. The periodicity of its appearance in dangerous numbers is due directly to the rise and fall in numbers of its parasites and natural enemies.

This scale is discussed and figured in Bulletin No. 22, n. s., and in Circular No. 64, U. S. Bureau of Entomology, under the name of Pulvinaria innumerabilis Rathv., but a careful study of our insect in this country reveals absolutely no differences from the common European species, P. vitis (Linn.). Fitch's types have also been compared, resulting in the above synonymy. A study of several supposed species and varieties of Pulvinaria, consisting of transplantings 
of young crawling larve from various hosts in different parts of the country to other hosts, and the subsequent changes in size and outward appearance, has convinced the writer that the host plant has an unexpectedily potent influence in the development of the insect. During the great outbreak of this scale in Chicago and vicinity in 1906, the writer brought from Chicago twigs of maple and box-elder with hundreds of the egg-sacs filled with eggs, and tied the twigs to a number of kinds of trees. In due time the eggs hatched and many of the larve set and molted and developed very satisfactorily on their new food plants, while on some trees a large percentage failed to develop.

The following spring and early summer brought forth a revelation in the various sizes, colorations and markings of the rapidly developing females on the various food plants. On young rapidly growing sycamore (Platamus occidentalis) and linden (Tilia americana) which were well cared for in large pots, the adult females just before the formation of the ovisac averaged $8 \mathrm{~mm}$. in length and $6 \mathrm{~mm}$. in breadth, and were mottled and marked with unusual brilliancy. The smallest females obtained in this experiment were grown on boxwood (Buxus sempervirens) and averaged but $2.75 \mathrm{~mm}$., while bat four specimens reached maturity. Transplantings were successful on apple, pear, quince, mulberry. grape, osage-orange, poison ivy (Rhus toxicondendron), Ampelopsis tricuspidata, plum, boxwood, spiræa, maple, box-elder, Viburnum prunifolium, Quercus coccinea, Ptelea

Explanation of Plate 19

1. Pseudocaccus adonidum Linn.

2. Pseudococcus citri Risso.

3. Toumeyella liriodendri Gmel.

4. Coccus hesperidum Linn. on Oleander leaf.

5. Lecanium caryo Fitch.

6. Lecanium nigrofasciatum Pergande.

7. Lecanium corni Bouché.

8. Lecanium persice (Fab).

9. Lecanium quercifex Fitch.

Nos. 5-9 are natural size and photographed simultaneously.

10. Orthezia insignis Dougl.

11. Asterolecanium variolosum (Ratz.) on Oak.

12. Cocous elongatus (Sign.) on Mimosa.

13. Neolecanium cornuparvum (Thro) on Magnolia twig.

14. Pulvinaria acericola Walsh \& Riley.

15. Lecaninu corni Bouché on Honeysuckle.

16. Saissetia hemispharica (Targ.) on Persea gratissima. 
December, '09] JOURNAL OF ECONOMIC ENTOMOLOGY

Plate 19

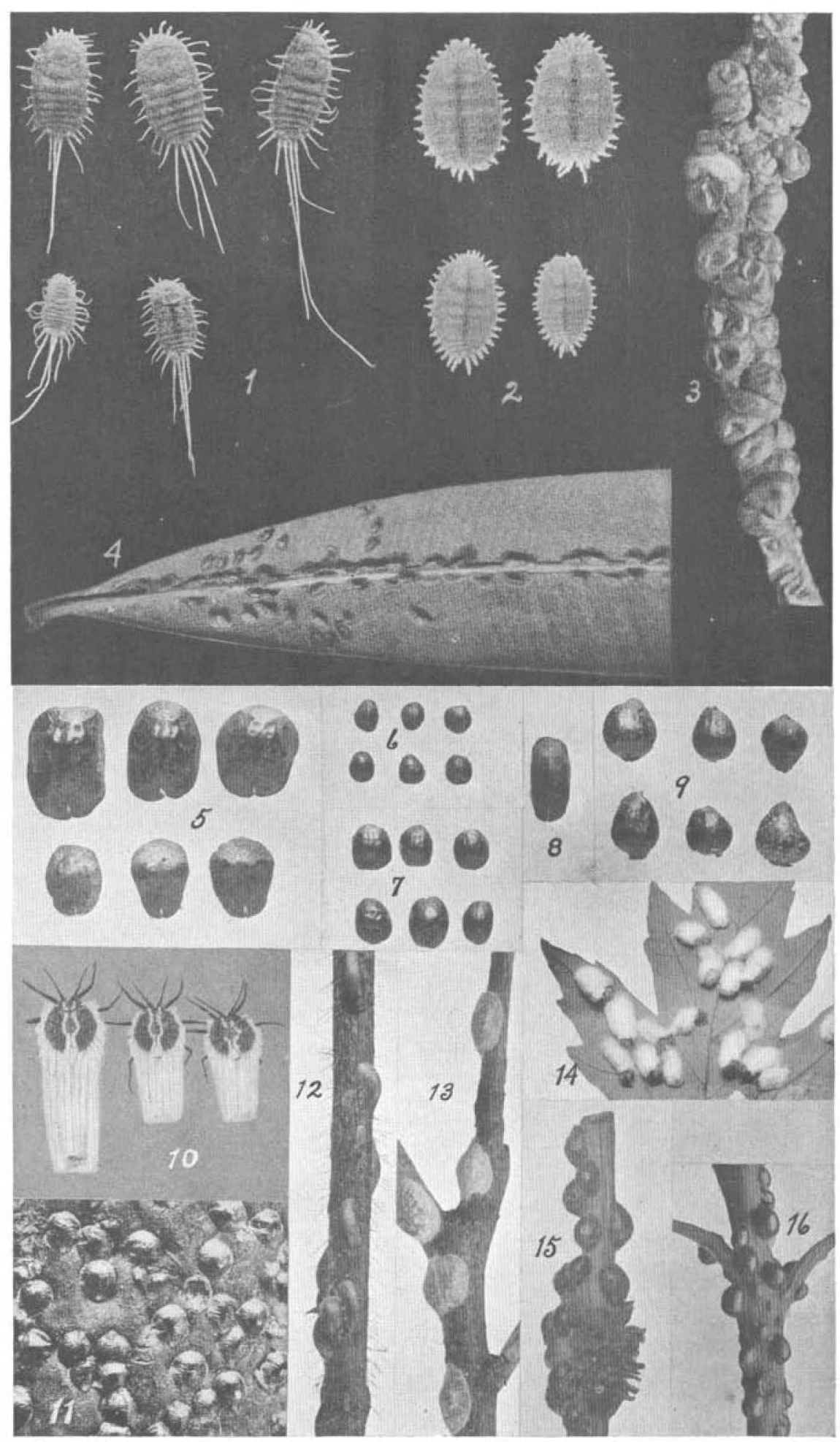

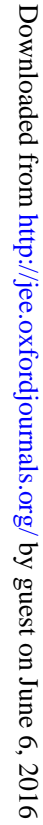


trifoliata, honey locust, American elm and hackberry (Celtis occidentalis). The superficial appearance of the adult females on different host plants varied remarkably as did also the size and bulk of the ovisacs.

Further study may reveal other synonyms of this species in the United States and Europe. Newstead, in his Monograph of British Coccidx, has reduced many species names of the early authors to synonymy with $P$. vitis.

\section{The Cottony Maple-Leaf Scale}

Pulvinaria acericola (Walsh \& Riley)

Plate 19, Fig. 14

Lecanium acericola W. \& R., Amer. Ent., I, p. 14 (1868).

Pulvinaria acericola Ckll., Check List, p. 329 (1896).

This species in the adult stage is usually found only on the leaves of maple, while $P$. vitis occurs invariably on the branches or twigs of its host. This habit means that the latter species, which develops in the younger stages on the leaves and migrates to the twigs before the falling of the leaves, changes location but once, while $P$. acericola migrates twice during its life history, $i$. e., from leaf to twig in autumn, and back to the new leaves in the following spring.

The females of acericola are very distinct from vitis in the more adult stages, having small patches of cottony wax on the dorsum, and developing a very long, fluted ovisac, which is narrower than that of vitis. The microscopic characters are also distinctly different. A complete illustrated discussion of the life history and habits of this scale-insect appeared in Bulletin 22, n. s., U. S. Bureau of Entomology in 1900 .

\section{The Tessellated Scale}

Eucalymnatus tessellatus (Sign.)

Plate 20, Fig. 1

Lecanium tessellatum Sign., An. Soc. Ent. Fr., 5, III, p. 401 (1873).

Lecanium perforatum Newst., Ent. Mon. Mag., XXX, p. 233 (1894).

Lecanium tessellatum var. perforatum Ckll., Psyche, VIII, p. 90 (1897).

Eucalymnatus tessellatus Ckll., Ann. Mag. N. H., 7, IX, p. 453 (1902).

Lecanium subtessellatum Green, Cocc. of Ceylon, pt. III, p. 206 (1904).

This species infests a wide range of food plants and is almost unmistakable in appearance. It is exceedingly flat, usually asymmetrical, brown to dark brown, and reveals its remarkable tessellation to the unaided eye. Under the microscope the beautiful pattern is disclosed 
and the derm appears as if composed of nicely fitted plates riveted together, so remarkable is the arrangement of small pores around the margins of the plates. The entire derm is full of pores of various kinds.

Newstead described a supposedly new species, called perforatum on account of a series of ten rather large pores in some of the posterior submarginal plates, which Signoret failed to mention in his description of tessellatus, a character which might easily have been omitted among the other more remarkable characters of this species. There are specimens of this species in the Fitch Collection at Washington from Signoret, and these all show the "perforations." The writer has examined hundreds of specimens of this species and all exhibit this same character.

Green in 1904 described from Ceylon, as subtessellatum, what he considered a new species, because the specimens he had at hand were apparently immature and lacked the strong tessellation in the middorsal region. Later Mr. Green has recalled the species after examining a larger series of these scales, and considers the above synonymy as correct.

\section{The Soft Brown Scale \\ Coccus hesperidum Linn. Plate 19, Fig. 4}

Coccus hesperidum Linn., Syst. Nat. Ed. X, I, p. 455 (1758). Chermes hesperidum Geoff., Abr. Ins., I, p. 505 (1762).

Calypticus hesperidum Costa, Faun. Reg. Nap., Cocc., p. 8 (1835), Calypticus lavis Costa, Faun. Reg. Nap., Cocc., p. 8 (1835). Calymmatus hesperidum Costa, Nuov. Osserv., p. 22 (1835). Coccus patelliformis Curt., Gard. Chron., p. 517 (1843). Chermes lauri Bdv., Ent. Hort., p. 340 (1867).

Lecanium platycerii Pack., Rep. Mass. Bd. Agr., p. 260 (1870). Lecaninum angustatum Sign., An. Soc. Ent. Fr., 5, IrI, p 398 (1873). Lecanium maculatum Sign., An. Soc. Ent. Fr., 5, III, p. 400 (1873). Lecanium alienum Dougl., Ent. Mon. Mag., XXIII, p. 77 (1886). Lecanium depressum var. simulans Dougl., Ent. Mon. Mag., XXIV, p. 28 (1887).

Lecanium minimum Newst., Ent. Mon. Mag., XXVII, p. 141 (1892). Lecanium assimile var. amaryllidis Ckll., Tr. Am. Ent. Soc., XX, p. 53 (1893).

Lecanium terminalice Clill., Jn. Inst. Jam., I, p. 254 (1893).

Lecanium nanum Ckll., Psyche, VII, Suppl., 1, p. 19 (1896-).

Lecanium flaveolum Ckll., Psyche, VIII, pp. 52, 53 (1897).

Lecanium minimum var. pinicola Mask., N. Z. Trans., XXIX, p. 310 (1897). Lecanium ventrale Ehrh., Can. Ent., XXX, p. 245 (1898).

Lecanium (Calymnatus) hesperidum pacificum Kuw., Jn. N. Y. Ent. Soc., $\mathrm{X}$, p. 30 (1902).

Lecanium signiferum Green, Cocc. of Ceylon, pt. III, p. 197 (1904). 
The fact that this scale has been redescribed so frequently under different names in various countries is alone proof of its exceptional importance to horticulturists and gardeners and of its widespread occurrence and great range of food plants. It is improbable that any other species of the soft scales is known to infest so many species of plants in widely divergent genera. In the writings of the very early European entomologists relating to scale insects, this species was always the preëminent one, from which we may assume that it was then the most important economic species of the region. At the present time it is a pest in those regions where it is permitted to multiply through the carelessness of man, or on account of favorable climate, or both combined.

The following description of the adult female by E. E. Green (Coccidæ of Ceylon, p. 188, 1904) is quite complete and furnishes an idea of some of the variations in markings, etc., which are found in this species.- "Adult female bright yellow or greenish-yellow, minutely specked with red-brown, the specks sometimes agglomerated into transverse bars, especially on the median abdominal region: in other parts tending to form dotted lines radiating from center to margin. In older examples the ground color may be ochreous or pale fulvous; and the maculation may form a broad median fascia. Under surface of older examples with a deep purple-brown or red patch covering the median abdominal area, becoming concave and forming a shelter for the young larvæ. Dried specimens straw-colored and much wrinkled. Form oblong-oval, often very irregular in outline; narrowest in front; more or less concave above according to age. In some individuals, generally on those protected by some shelter, I have noticed a double median longitudinal series of raised glassy points; but they appear to be very brittle and edsisily lost." Length, 2.5-5 mm.; breadth, 1.5-3 mm.

In view of the great variation in size, color and markings, there are plausible excuses for the frequent redescriptions of this cosmopolitan species under new names; but entomologists should take into account a certain probable variability in any insects they describe as new or otherwise.

Some of the above synonymy is here proposed for the first time, but several names have been reduced by Newstead, Green and Fernald. For the reduction of angustatum, maculatum, terminalice, nanum, flaveolum, minimum, var. pinicola, ventrale, hesperidum var. pacifcum, and signiferum, the writer is responsible. These reductions are made only after very careful morphologic study with a high power microscope of typical material, and after biological study of the forms 
so far as possible on many food plants. Resulting variations secured by transference to different food plants, were fully as remarkable as observed in the case of Pulvinaria vitis (L.).

\author{
The Long Soft Scale \\ Coccus elongatus (Sign.) \\ Plate 19, Fig. 12
}

Lecanium elongatum Sign., An. Soc. Ent. Fr., 5, III, p. 404 (1873).

Lecanium longulum Dougl., Ent. Mon. Mag., XXIV, p, 97 (1887).

Lecanium chirimolice Mask., N. Z. Trans., XXII, p. 137 (1889).

Lecanium ficus Mask., Ent. Mon. Mag., XXXIII, p. 243 (1897).

Lecanium frontale Green, Cocc. Ceylon, pt. III, p. 192 (1904).

This species is quite similar in general appearance to $C$. hesperidum with its color variations, but is elongate elliptical to varying degrees, depending upon the exigency of location; and is ordinarily rather more convex than the latter species. The eight-segmented antennæ will identify it easily from those of hesperidum with but seven. The latter species has but four fringe spines arranged in a transverse line about midway across the anal plates, while there are eight in elongatus.

The specific name elongatum Sign., takes precedence over longulum Dougl., since an examination of specimens from Signoret in the Fitch collection verifies this synonymy. $L$. chirimolice and $L$. ficus of Maskell are also synonyms. $L$. frontale Green has been a puzzle for some time because the writer could find no morphologic characters to differentiate it from elongatus, except its more narrow form. But the discovery of elongatus on leaves of Anthurium, Calophyllum and Croton exhibiting all the forms connecting the typical elongatus and typical frontale has cleared the situation. On these plants the young scale has settled close to the high midribs or larger veins and its development has been more linear than usual, resulting in the greater length of body anterior to the antennæ and posterior to the anal plates. In all microscopic characters-derm pores, antennæ, legs,

Explanation of Plate 20

Photomicrographs showing characteristic derm pores; all at same magnifcation.

1. Eucalymnatus tessellatus (Sign.).

2. Saissetia olea (Bern.).

3. Saissetia nigra (Nietn.).

4. Saissetia hemisphorica (Targ.).

5. Toumeyella liriodendri (Gmel.).

6. Neolecanium cornuparvum (Thro). 


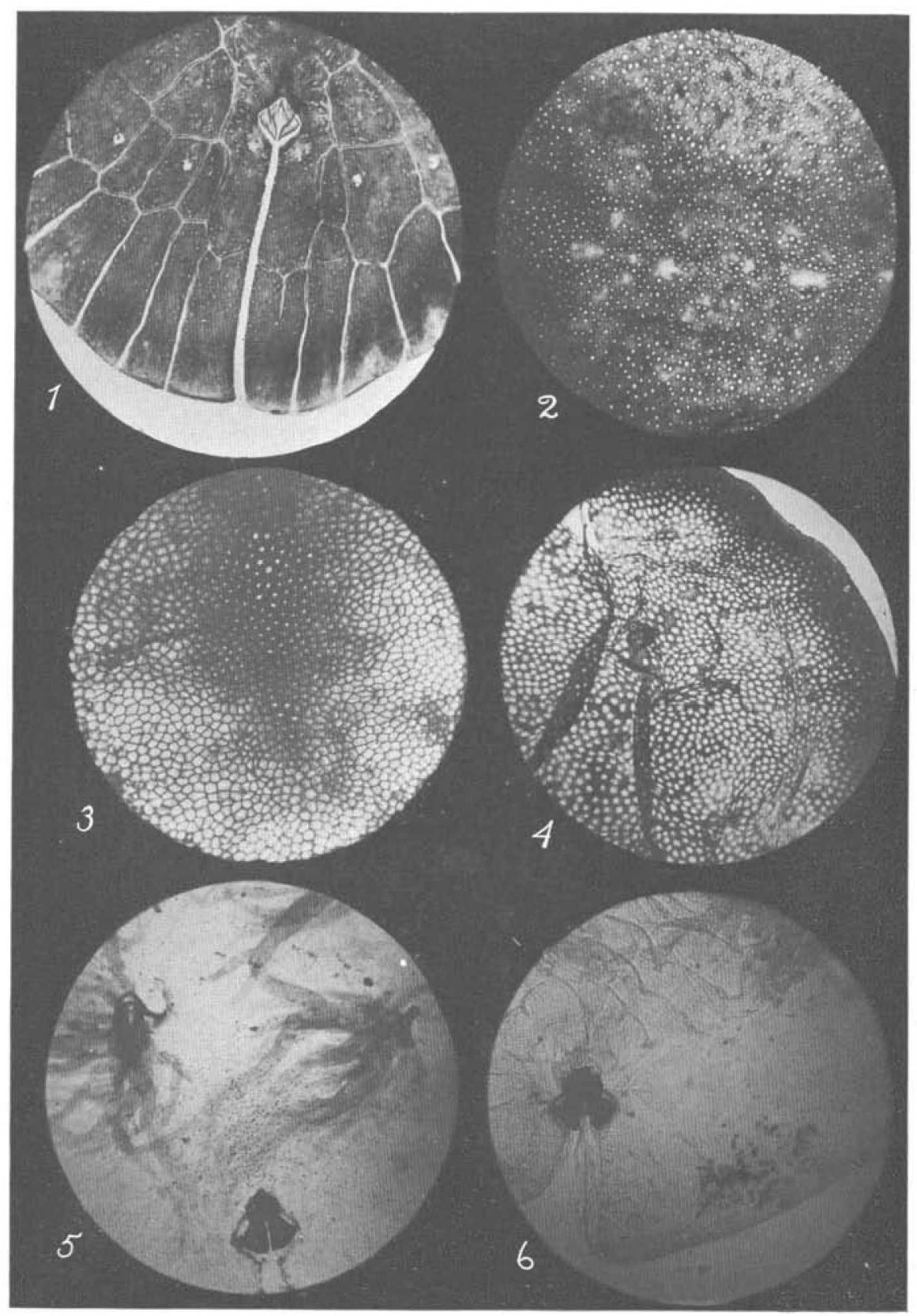


marginal and spiracular spines, anal plates and spines-the similarity is evident.

\author{
The Hemispherical Scale \\ Saissetia hemispharica (Targ.) \\ Plate 19, Fig. 16; Plate 20, Fig. 4
}

Lecanium hemispharicum Targ., Studii sul. Cocc., pp. 26, 27, etc. (1867).

Chermes anthurii Bdv., Fnt. Hort., p. 328 (1867).

Chermes filicum Bdv., Ent: Hort., p. 335 . (1867).

Chermes hibernaculorum Bdv., Ent. Hort., p. 337 (1867).

Lecanium coffea Sign., Ann. Soc. Ent. Fr., 5, III, p. 435 (1873).

Lecanium beaumontice Dougl, Ent. Mon. Mag., XXIV, p. 95 (1887).

Lecanium clypeatum Dougl., Ent. Mon. Mag., XXV, p. 58 (1888).

Lecanium hemispharicum var. hibernaculorum Ckll., Bul. Bot. Dep. Jamaica, p. 71 (1894).

Lecanium hemisphcericum var. flicum Green, Ent. Mon. Mag., XXXIII, pp. 70,77 (1897).

Lecanium (Saissetia) coffea var, clypeatum Ckll. \& Parr., The Industrialist, p. 164 (1899).

Saissetia hemisphorica Ckll., The Ent. Student, II, p. 32 (1901).

Coccus coffece Kirkaldy, Fauma Haw, III, pt. 2, p. 105 (1902).

The common name of this scale is descriptive of its form, although it is not exactly hemispherical but a little elongate and frequently higher than broad. The shape, smooth surface, brown color, and the minute pale dots of the skin which are easily seen with the aid of a hand-lens, will distinguish this common species. As in all species of this genus, the derm is filled with microseopic pores.

A number of species and varieties have been described by early authors which are now known to be synonyms. A form known as filicum, occurring on ferns has been held to be a different species, but a long study of this form and its transference from various hosts to ferns and vice versa indicates that not even varietal rank should be considered.

Mr. W. C. Thro, in Bul. 209, Cornell Univ. Agr. Exp. Sta., describes filicum as varying from hemisphcerica in the number of "fringe spines" on the anal plates, but a careful examination of Mr. Thro's slides reveals the ordinary number of spines, although small, in his specimens which were immature.

This species is perhaps more widely (if possible) distributed throughout the world than $S$. olece, and infests a wider range of plant life. It occurs only in greenhouses in temperate regions. 
The Olive Scale.

\author{
Saissetia olew (Bern.)
}

Plate 20, Fig. 2

Chermes olea Berm., Mem. d'Hist. Nat. Ac. Marseille, p. 108 (1782).

Coccus olea Oliv., Ency. Meth., VI, p. 95 (1791).

Coccus palmo Haw., Tr. Ent. Soc. Lond., p. 307 (1812).

Coccus testudo Curt., Gard. Chron., p. 444 (1843).

Coccus cycadis Bdv., Ent. Hort., p. 323 (1867).

Lecanium cassinice Mask., N. Z. Trans., XXIII, p. 15 (1890).

Lecaninum olew var, testudo Clkll., Check List, p. 331 (1896).

Lecunium olew var, mirandum Ckll. \& Parr., Biol. Centr. Am., II, pt. 2, p.

12 (1899).

Coccus olea Kirlialdy, Fauna Haw., III, pt. 2, p. 106 (1902).

In view of the fact that this species has been described and figured so frequently in various reports, it seems hardly necessary to describe it again in full. The popular name "black scale" has been applied to this species, but rather incorrectly, since it is usually very dark brown; the above name should be applied properly to Saissetia nigra, which in the adult female stage usually becomes truly black.

A thorough study of this species warrants the above synonymy, part of which Professor Newstead proposes and the remainder is vouched for by the writer after examining typical material. Maskell, in his notes, doubts the validity of his species, cassinia, and an examination of his types sinks the name.

This species is readily recognized by its thick convex, dark-brown scale dotted with minute flakes of wax, and bearing two more or less prominent transverse ridges and a median longitudinal ridge in the form of a letter $H$. The young female of the hemispherical scale sometimes exhibits this character to a slight degree, but it vanishes toward maturity.

The olive scale infests a wide range of food plants and is found in nearly every greenhouse where tropical plants are grown, and is a pest in the warmer regions of the United States.

\title{
The Black Scale \\ Saissetia nigra (Nietn.)
}

Plate 20, Fig. 3

Lecanium nigrum Nietn., "Enemies of Coffee-tree," p. 9 (1861).

Lecanium depressum Targ., Studii sul. Cocc., p. 29 (1867).

Lecanium begonice Dougl., Ent. Mon. Mag., XXVIII, p. 209 (1892).

Lecanium nigrum var. depressum Ckll., Check List, p. 332 (1896).

Saissetia depressa King, Psyche, IX, p. 296 (1902). 
Saissetia nigra King, Psyche, IX, p. 296 (1902).

Saissetia nigrella King, Psyche, IX, p. 296 (1902).

Coccus nigrum Kirkaldy, Fauna Haw., III, pt. 2, p. 106 (1902).

This species is of less importance in the United States than either of the other species of this genus mentioned here. Its distribution has been effected to all quarters of the globe, occurring on many different plants. In some of the West Indian Islands it is a very important cotton pest and difficult to control.

It is included in this paper principally to record its synonyms which have been described from various regions and until recently held as distinct species.

\section{The European Peach Scale \\ Lecanium persicae (Fab.) \\ Plate 19, Fig. 8}

Chermes persicce Fab., Gen. Ins. Mant., p. 304 (1776).

Chermes clematitis Gmel., Syst. Nat., Ed. XIII, p. 2220 (1789).

Lecanium cymbiformis Targ., Catalog. Coccidarum, p. 37 (1868).

Lecanium berberidis Sign. (non. Schr. ${ }^{1}$ ) Essais, p. 233 (1873).

Lecanium genistce Sign., Essais, pp. 235, 484 (1873).

Lecanium persica Sign., Essais, p. 237 (1873).

Lecanium rosarum Sign., Essais, p. 257 (1873), (non Sn. v. Voll., 1862).

Lecanium berberidis Mask., N. Z. Trans., XXIX, p. 311 (1897).

Lecanium subaustrale Ckll., The Entom., XXXI, p. 131 (1898).

Lecanium magnolianum Ckll., Ent. News, IX, p. 146 (1898).

Lecanium magnoliarum var. hortensia Ckll., Psyche, X, p. 19 (1903).

The genuine $L$. persicae is a large chestnut brown species $5-7 \mathrm{~mm}$. long with 8-segmented antennae as described by Signoret. It is much less convex than $L$. corni and is sometimes rather flattened toward the margins. The 24 to 28 large conspicuous pores in a submarginal row will also aid in identifying this species.

It apparently has been recorded in the United States only from California under the name of Lec. magnoliarum.

${ }^{1}$ Coccts berberidis Schrank, Fauna Boica, II, Abt. 1 (1801) is not a Lecanium at all, but the description surely refers to Mytilaspis pomorum. "Schinkenmuschelförmig. dunkel rothbraun, weislicht gerandet, am schmälern Ende rostbraun." Freely translated is-Oystershell-shape, dark red brown, palemargined, rust-brown at the small end. Schrank also refers to the impure white eggs occurring beneath the dead body of the female in April, which is too early for such a record of a Lecanium in a temperate region. 
The Frosted Scale

Lecanium pruinosum Coquillett.

Leaanium pruinosum Coq., Ins. Life, III, p. 382 (1891).

Lecanium robinice Towns., Bull. 7, N. Mex. Bxp. Sta., p. 11 (1892).

Lecanium robiniarum Ckll. (non Dougl.) Can. Ent., XXVII, p. 257 (1895).

Eulecanitum robinice var. subsimile Ckll., The Bntom., XXXV, p. 178 (1902).

This species, which has been of some economic importance in California, seems to be a native of the highlands of Mexico, whence it has been introduced to the fruit districts of the above State. The synonymic variety subsimile, which occurs on ash or Rhus (?) in Mexico, points to this region as the probable home of $L$. pruinosum. The specific name is descriptive of this species when it is covered with fine powdery wax, but this character is not always evident in some localities where it occurs. Its general appearance is like a very large $L$. corni, very convex, dark reddish brown, variously pitted and grooved; the 7-jointed antennæ and the legs and other characters are quite similar to corni, but the derm pores furnish the most evident character for the species, as will be seen by reference to the photomicrograph of the derm. The pores are small, clearly defined, and regularly arranged, but they do not show a tendency to arrange themselves in broken rows perpendicular to the margin as in $L$. corni.

This species occurs in California on the apricot, peach, plum, prune, pear, apple, ash, locust, English walnut, grape, rose, etc. In New Mexico, Arizona and Mexico there may be many other hosts.

\section{The Hickory Lecanium \\ Lecanium caryce (Fitch) \\ Plate 19, Fig. 5}

Lecanium caryoe Fitch, 3d Rep. Ins: N. Y., p. 125 (1856).

Lecanium cockerelli Eunter, Kan. Univ. Quar., VIII, p. 70 (1899).

Eulecanium carya King, Can. Ent, XXXIV, p. 160 (1902).

Contrary to published reports, Fitch's types of this species are in the national collection at Washington in good condition, so that we know the species accurately. There is little possibility that any one should confuse it with any of our other Lecaniums on account of its enormous size; length, 10-13 mm.; breadth, 7-9 mm., and height, 3-5 mm. The buff or yellowish-brown color of the developing female changes after oviposition to a beautiful deep reddish brown dusted with waxy powder.

This species is a victim of several species of minute hymenopterous 
parasites, which usually distort its normal shape and size to a remarkable degree. Many specimens collected in Ohio by the writer from elm, hickory, willow, peach, etc., are so distorted that they would not be recognizable if met with singly. A microscopic examination will surely determine the species, however, if the unusually numerous, large marginal spines are noted, along with the ordinary 6-7 segmented small antenna.

That Lecanium cockerelli Hunter is but a parasitized and distorted form of this species, is the conclusion reached by the writer after collecting and examining many specimens along with Professor Hunter's types. The fact, as reported in the original description, that the tree bearing the types of this form was badly infested, and the following year was almost free from this scale, would suggest almost complete parasitism.

\section{The European Fruit Lecanium \\ Lecanium corni (Bouché)}

Plate 19, Figs. 7,15

Lecanium corni Bouche, Stett. Ent. Zeit., V, p. 298 (1844).

Lecanium tilice Fitch (non Linn.), 4th Rep. Reg. Univ. N. Y., p. 69 (1851).

Lecanium pyri Fitch (in part), Tr. N. Y. St. Agr. Soc., p. 809 (1854).

Lecanium cerasifex Fitch, 3d Rep. Ins. N. Y., p. 50 (1859),

Lecanium ribis Fitch, 3d Rep. Ins. N. Y., p. 109 (1859).

Lecanium oynosbati Fitch, 3d Rep. Ins. N. Y., p. 118 (1859).

Lecanium juglandifex Fitch, 3d Rep. Ins. N. Y., p. 145 (1859).

Lecanium corylifex Fitch, 3d Rep. Ins. N. Y., p. 155 (1859).

Lecanium fitchii Sign., Ann. Soc. Ent. Fr. (5), III, p. 404 (1873).

Lecanizm tarsale Sign., Ann. Soc. Ent. Fr. (5), III, p. 430 (1873).

Lecanium armeniacum Craw, Rep. Cal. Bd. Hort., p. 12 (1891).

Lecanirlm robinia Towns., Bull. 7, N. Mex. Exp. Sta., p. 11 (1892).

Lecanium carye var. canadense Ckll., Can. Ent., XXVII, p. 253 (1895).

Lecanium lintneri Ckll. \& Benn., Am. Nat., XXIX, p. 381 (1895).

Lecanium crawii Ehrh., Can. Ent., XXX, p. 245 (1898).

Lecanium caryarum Ckll., Can. Ent., XXX, p. 293 (1898).

Lecanin machurarum Ck11., Can. Ent., XXX, p. 294 (1898).

Lecanium kingii Ckll., Ann. Mag. N. H. (7), II, p. 322 (1898).

Lecanium kansasense Hunter, Kan. Univ. Quar., VIII, p. 69 (1899).

Lecanitum aurantiacum Hunter, Kan. Univ. Quar., IX, p. 107 (1900).

Lecanium websteri King, Can. Ent., XXXIII, p. 106 (1901).

Eulecanium guignardi King, Can. Ent., XXXIII, p. 334 (1901).

Eulecanium rose King, Can. Ent., XXXIII, p. 336 (1901).

Lecanium adenostome Kuwana, Pr. Cal. Ac. Sci. (3), II, p. 402 (1901).

Eulecanium fraxini King, Can. Ent., XXXIV, p. 158 (1902).

Lecaniam obtusum Thro, Bull. 209, Corn Univ. Expt. Sta., p. 212 (1903).

Eulecanium folsomi King, Can. Ent., XXXV, p. 193 (1903). 
Besides the above long list of American synonyms, Dr. P. Marchal in his excellent treatise on European scale insects has designated the following European species as synonyms, viz., vini Bouché, 1844; rosarum Snell v. Voll., 1862; mori Sign., 1873; coryli Sign., 1873; rugosum Sign., 1873; wistarice Sign., 1873; sarothamni Dougl., 1891; assimile Newst., 1892 ; rehi King, 1901; persicce Newst., 1903 ; persice var. coryli Newst., 1903; persica var. sarothamni Newst., 1903.

What Muse guided the minds of entomologists while describing this species under its various aliases, the writer scarcely dares conjecture. A certain spell of belief or unbelief, whichever you may choose, must have worked its charm at the psychological moment causing each new lot of specimens from a new locality or food-plant to appear as specifically distinct.

We have also, as bases for new species, exceedingly careful measurements to the thousandth part of a millimeter, of the segments of the antennæ which may be 6-segmented on one side and 7-segmented on the other side of the same scale, or in the case of a parasitized specimen may be 8 -segmented or only 5 -segmented.

Then again we have what may be designated as "honor" species, since more valid reasons for their existence seem to be lacking, such as fitchii, lintneri, websteri, etc. It is well that the integrity and honor of those bearing these names will not be shattered by the downfall of the species dedicated to them.

For several years the writer has carefully added species after species to the synonymy of this exceedingly common Lecanium, only after examining the types or cotypes. The writer has studied the types of all the above names with the exception of four, and in those cases similar topotypic material was seen. Sufficient breeding work in transferring species from tree to tree, with their attendant changes in appearance, was carried out to convince the writer that his observations on the behavior of the cottony maple scale were almost duplicated in this species. Remarkable changes are wrought in the individual scales when transferred to a new host plant.

The synonymy of these species with $L$. cerasifex Fitch has been in hand for some time, but only this year, by means of material from Europe and with the aid of Dr. Paul Marchal's excellent studies on European Lecaniums, ${ }^{1}$ has the writer included this entire synonymy under $L$. corni Bouché.

This common species which occurs on so many of our economic and

${ }^{1}$ Notes sur les Cochenilles de l'Europe, Ann. Soc. Ent. France, Vol. LXXVII, pp. 223-309 (1908). Plate and text figures. 
wild trees and shrubs, is quite convex in form with irregular, varying rugasities and pits in the hard brown derm of the adult or dead female. Various fuscous transverse and longitudinal markings are evident on the young adult female scale before oviposition in early summer. These markings rapidly disappear at her death and darker brown suffuses the derm, leaving sometimes a trace of fuscous on the dorsum.

The cleared derm appears brownish, antennæ 6 or 7 -segmented, usually the latter; legs well developed, ordinary; anal plates heavily chitinized, together forming nearly a square; 6 large and 2 small hairs, on the anal ring; marginal spines rather short and stout 18-24 $\mathrm{mmm}$. in length; spiracular spines variable, rather slender, the shorters ones $30-40 \mathrm{mmm}$. and the middle one $50-60 \mathrm{mmm}$. in length. The cleared derm shows extra heavy chitinization of the regions along the anterior margin extending inward toward the antenne, and also of the posterior lobes near the cleft. The characteristic general arrangement of the many derm pores in very irregular, broken and interrupted radiating rows, is especially noticeable near the margin. In some specimens this character is not so marked.

This species occurs widely in North America on a very great range of mostly deciduous trees and shrubs. In a few instances it has become of economic importance, but not for long on account of its control by natural enemies and parasites. This species determined under various names threatened the plum orchards of New York state a few years ago, and more recently has been occasionally reported from various states of the middle-west as a pest on elm, mulberry, osage-orange and linden.

The range of this species includes practically every state in the Union, and its host-plant list is lengthy; the more important hosts are plum, peach, apricot, pear, currant, blackberry, mulberry, osageorange, elm, ash, linden, pecan, maple, Cornus, etc.

\section{The Oak Lecanium}

\section{Lecanium quercifex Fitch}

Plate 19, Fig. 9

Lecanium quercifex Fitch, 5th Rep. Ins. N. Y., p. 25 (1859).

Lecanium quercitronis Fitch, 5th Rep. Ins. N. Y., p. 25 (1859).

Lecanium antennatum Sign., Aun. Soc. Ent. Fr. (5), III, p. 413 (1873).

Lecanium pruinosum var. kermoides Tyrrell, Rep. Cal. Exp. Sta., p. 256 (1896).

Fitch's two species were described from white and black oak respec- 
tively, but the types are identical. This very convex species seems restricted principally to oaks for the writer has attempted several times to transfer it to several other trees but failed to obtain adults, though the larva lived for some time on the strange host-plants.

This species is very convex, sometimes broader at the summit than at the point of attachment; light brown with a variable dark marking in the mid-dorsal region. The antennæ and legs are unusually long and slender; the derm pores (see photomicrograph) are rather large and regularly scattered but far apart; the spiracular and marginal spines are more slender than in corni or pruinosum. This species can be recognized by the three or four apparent scars near the outer angles of the anal plates, which otherwise are quite similar to those of $L$. corni.

The range of this species is very general, but it is of particular economic importance to the oaks in the south Atlantic and Gulf states. Signoret described his species antennatum from specimens on oals sent to him by Fitch from New York state.

\section{The Globular Scale \\ Lecanium prunastri (Fonsc.)}

Coccus prunastri Fonsc., An. Soc. Ent. Fr., III, p. 211 (1834).

Lecanium prunastri Sign., An. Soc. Ent. Fr., V, p. 423 (1873).

Lecanium rotundum Sign., An. Soc, Ent. Fr., V, p. 428 (1873).

Eulecanium prunastri Fernald, Catalogue of Coccidæ, p. 193 (1903).

This almost globular, small dark-red species is fairly common in Europe, but is found in few localities in the United States outside of Pennsylvania, where it has been known for a number of years. It infests principally plum, cherry and peach, and is remarkably gregarious in habit.

The best microscopic character of this species is the compound row of 100 or more small derm pores extending anteriorly from the anal plates. A stained specimen shows this character more satisfactorily than an untreated one.

$$
\begin{gathered}
\text { The Terrapin Scale } \\
\text { Lecanium nigrofasciatum (Pergande) } \\
\text { Plate 19, Fig. } 6
\end{gathered}
$$

Lecanium nigrofasciatum Perg., Bul. 18, n. s., Bur. Ent., U. S. Dep. Agr., p. 26 (1898).

The original description of this native scale in the above reference and Circular No. 88, of the U. S. Bureau of Entomology, containing 
a popular discussion and a short technical description of the species, are available to most entomologists, so that an extended discussion in this paper is hardly necessary.

Previous to Mr. Pergande's description of this species, it had been for many years confused with Lecanium persica of Europe, on account of its frequent occurrence on peach trees in this country. At present its general range is limited to the eastern half of the United States, including a few states just west of the Mississippi River. Its food plant list is large and comprehensive, including some of our most important economic and ornamental trees and shrubs.

Its habit of overwintering on the branches of its host plant, in a half-grown stage, is unique among Lecaniums. In microscopical details this species shows relationship with the genus Toumeyella and with Lecanium, and in view of its remarkable life history it may some day require a new genus for its proper reception.

\section{The Tulip Soft Scale \\ Toumeyella liriodendri (Gmel.)}

-Plate 19, Fig. 3; Plate 20, Fig. 5

Coccus liviodendri Gmel., Syst. Nat., Ed. XIII, p. 2220 (1789).

Lecanium tulipiferce Cook, Can. Ent., X, p. 192 (1878).

Lecanium tilice Cook, Ent. Amer., I, p. 211 (1885).

Eulecanium tulipiferce King, Can. Ent., XXXIV, p. 60 (1902).

Eulecanium liriodendri Fernald, Cat. Coccidæ, p. 190 (1903). $:$

A tree badly infested with this species presents a more disgusting appearance than any other of our common soft scales. Although quite confined to Liriodendron tulipifera as a host plant, it occasionally is found on Magnolias, but is easily distinguished from the larger, flatter magnolia soft scale by its very convex irregular form and dull clay-yellow color.

This species has been erroneously classified in Eulecanium. The character of its antennæ and legs which are reduced to mere stubs preclude any relationship with Lecanium persica, $L$. prunastri, etc., but instead relegates it to the genus Toumeyella, with which group it has derm characters in common.

This species was first described in Europe as C. liriodendri from Liriodendron trees imported from America, then about a hundred years later was described in America under the name tulipiferce. During these years these two names have been held as representing distinct species, and more recently have been placed under the subdivision Eulecanium where they have no relationship. 


\section{The Magnolia Soft Scale}

Neolecanium cormuparvum (Thro.)

Plate 19, Fig. 13; Plate 20, Fig. 6

Lecanium cornuparvum Thro, Bul. 209, Cornell Exp. Sta., p. 216 (1903).

This large flat scale has been erroneously determined and discussed by a few writers under the name $L$. magnoliarum, and has existed scientifically undescribed until 1903, although not an uncommon insect. It occuirs on various species of Magnolias, including the deciduous $M$. acuminata of the Northern States. The pink color of the growing female scale is somewhat hidden by the covering of fine powdered wax, which also fills the spiracular grooves on the ventral surface and remains as four distinct white lines after the removal of the scale from its host.

The adult females average $8-10 \mathrm{~mm}$. long and $5-8 \mathrm{~mm}$. broad. When cleared and mounted the derm is seen to be crowded with large pores, and the very short reduced antennae and legs are scarcely noticeable.

It has been reported from New York, Ohio, Pennsylvania, Maryland, Virginia and Louisiana.

\section{A NEW ENEMY OF THE FLORIDA ORANGE}

By E. A. BACK, Orlando, Fla.

The purpose of this notice is merely to call the attention of Entomologists to the discovery for the first time in this country of another pest of the citrus tree. In view of the widespread havoc played among the orange groves of Florida by the Citrus white $\mathrm{fly}$, A. citri Riley and Howard, and the Spotted-wing, A. nubifera Berger, the discovery of another Aleyrodid which already has demonstrated itself to be of economic importance is interesting.

While recently examining orange trees along several streets in the business section of Tampa in connection with the white fly investigations being carried on in Florida by the Bureau of Entomology, the attention of the writer was attracted to dense white or grayish woolly secretions concealing the under surfaces of many leaves. At first this was supposed to be a heavy infestation of the usually scarce Paraley. rodes persece Quaintance, but on closer examination proved to be Aleyrodes howardi Quaintance, which until the present time has been known only to infest the orange trees of the West Indian Islands. In 